\title{
Cutaneous Melanoma pN2c TNM Finding v6
}

National Cancer Institute

\section{Source}

National Cancer Institute. Cutaneous Melanoma pN2c TNM Finding v6. NCI Thesaurus. Code C48862.

Cutaneous melanoma without involvement of regional lymph nodes, with satellite or intransit metastasis. (from AJCC 6th Ed.) 